\title{
The impact of bank-specific and macroeconomic variables on profitability of Islamic rural bank in Indonesia
}

\author{
1* Muhammad Sanusi, ${ }^{2}$ Siti Zulaikha \\ ${ }^{1,2}$ Fakulty of Economics and Business, Airlangga University, Indonesia \\ *Email korenpondensi: sanusimuhammad171@gmail.com
}

\begin{abstract}
This paper investigates the impact of bank-specific and macroeconomic variables on the profitability of Islamic rural bank (BPRS) in Indonesia. Using monthly time series data from January 2010 December 2018. The estimation model used is a vector error correction model to analyze the longterm and short-term relationships between bank-specific and macroeconomic variables on the profitability of Islamic rural bank. The results showed that CAR and LnTA had a significant positive relationship, while NPF, BOPO and IPI had a negative and significant relationship to the profitability of Islamic rural banks. But FDR and Inflation variables are not significantly related to the profitability of Islamic rural bank. The results leave implications for policy makers, investors and banking sector managers. Based on evidence that bank profitability is more influenced by internal banks (as specific as banks), this research can help Islamic rural banks to help them understand which factors are important to be analyzed to obtain higher profitability.
\end{abstract}

Keywords: Bank-specific, Islamic rural bank (BPRS), Macroeconomic, VECM

Saran sitasi: Sanusi, M., \& Zulaikha, S. (2019). The impact of bank-specific and macroeconomic variables on profitability of Islamic rural bank in Indonesia. Jurnal Ilmiah Ekonomi Islam, 5(03), 317 325. doi: http://dx.doi.org/10.29040/jiei.v5i3.635

DOI: http://dx.doi.org/10.29040/jiei.v5i3.635

\section{Introduction}

In any economy, banks have a primary role as financial intermediaries between unit surplus and deficit. A strong and profitable banking system can contribute significantly to the stability of the entire financial system by holding back the possibility of negative shock (Masood et al., 2015). Therefore, the determinants of profitability of sharia people's finance banks continue to attract the attention of all parties in the financial system.

At the micro level, profit is the essential prerequisite of a competitive banking institution. It is not just a result but also a requirement for successful business in a period of growing competition on financial markets. Hence, the basic aim of a bank's management is to realize profits, as the critical condition for conducting any business. The existence, growth and survival of a business organization mostly depend upon the profit which it is able to earn. At the macro level, a profitable banking sector is better able to endure negative shocks and contribute to the stability of the financial system (Menicucci \& Paolucci, 2016).

Bank profitability is generally considered an important condition for the long-term survival of bank institutions; In addition, these variables significantly affect the achievement of the company's financial goals. Bank profitability can 


\section{Jurnal Ilmiah Ekonomi Islam, 5(03), 2019, 318}

influence economic growth, increase employment, innovation and technological change. However, with increasing competition, increased efficiency, and price pressures, companies have difficulty achieving greater profitability. The question of what factors determine bank profitability must be one of the priorities for researchers and practitioners, including managers, investors, debt holders, and policy makers.

In general, bank's profitability can be influenced by internal and external factors. Internal factors such as, risk, and lending technology. External factors which are out of bank manager's control, i.e. contracting monetary policy or global financial crisis (Shaban et al., 2014). Therefore, understanding the determinants of bank profitability is very important for bank management and supervision. This study seeks to find answers to these questions about what determinants influence bank profitability internally (bank specific) and external (macroeconomic variables).

Islamic Banking Institutions in Indonesia are divided into two categories, Islamic Commercial Banks (BUS) and Islamic Rural Bank (BPRS). The focus of this study is on the Islamic rural bank's area. As one of the financial institutions, the Islamic rural bank is guided to maintain its performance. The most appropriate aspect to measure bank performance is to measure the value of profitability. The ratio that is often used to measure profitability performance is return on asset. The determinant factors that influence profitability are divided into two categories, namely internal (bank specific) and external (macroeconomic variables). The determinants of bank-specific are capital ratio, non performing finance, finance to deposit ratio, operational costs, and total assets (bank size). While macroeconomic variables are economic growth which is proxied by the Industrial Production Index, and Inflation.

There is a large amount of literature that examines the role of various factors in determining bank performance. The capital ratio is an appreciated tool for assessing capital adequacy, and it captures the general soundness of banks (Menicucci \& Paolucci, 2016). The capital ratio is proxied by Capital Adequacy Ratio (CAR). AL-Omar \& AL-Mutairi (2008) found that capital adequacy positive related to bank profitability. Salike \& Ao (2018) investigated the determinants of bank's profitability in Asia, uses fixed effect estimation for the panel data period from 2001-2015. The results show that adequacy ratio is positive related to profitability bank's in Asia.

Funding management is very important for banks, good financing as a revenue contributor for banks. One of the main problems at banks is the financing risk, the financing risk for commercial banks is non performing loans, while non performing finance for Islamic banks (Kusumastuti \& Alam, 2019). This study focuses on Islamic bank so that the financing risk variable is proxied by non performing finance. A high non performing finance ratio can affect the level of bank profitability. Laryea et al., (2016) investigate the bank-specific and macroeconomic determinants of non performing loans on bank profitability from an emerging market in Ghana period 2005-2010. The study found that non performing loans is negative related to bank profitability in Ghana. Yudha et al., (2017) found that non performing loan in domestic and foreign bank are negative and significant impact to bank profitability.

Liquidity can be defined as the ability to meet cash needs (cash flow) immediately and at the appropriate cost. The liquidity for commercial banks is loan to deposit ratio, while financing to deposit ratio for Islamic banks. The proxy used in this study in calculating Islamic bank liquidity is Financing to Deposit Ratio (FDR), which is how much Islamic bank funds are released for financing. Erlangga \& Mawardi (2016) analyse impact of bank specific on shariah bank profitability in Indonesia period from 2010 to 2014 using Double Linear Regression. The result showed that liquidity (FDR) has a positive and significant on shariah 
bank profitability. Yudha et al, (2017) analyse of the effect bank specific on domestic and foreign banks profitability. The result showed that in loan to deposit ratio in foreign bank has a negative and significant influence to bank profitability.

The operational cost ratio is used to measure the level of efficiency and ability of banks in conducting operations. Banks that have efficient operational costs can improve the performance of bank profitability. The operational cost ratio is proxied by Operating Cost of Operating Income (BOPO). Kusumastuti \& Alam (2019) analysis of impact CAR, BOPO, NPF on profitability of Islamic Banks period 2015-2017. The result showed that operating cost of operating income has a negative significant effect on bank profitability. Wibowo \& Syaichu (2013) examined impact of bank-sepcific and macroeconomic to profitability Islamic bank in Indonesia period from 2008 to 2011. This study found that operating cost of operating income has a negative significant effect on profitability of Islamic bank.

Bank size is generally used to capture the economic potential or scale of diseconomies in the banking sector, bank size is proxied by total asset (Tan \& Floros, 2012). Masood \& Ashraf (2012) examined bank-specific and macroeconomic determinants influence Islamic banks' profitability in the selected countries of different regions. The results show that total asset is positive related to bank profitability. The study about bank-specific determinants of profitability in Kuwait period from 1993 to 2005, using Seemingly Unrelated Regression (SUR). ALOmar \& AL-Mutairi (2008) found that total asset positive related to bank profitability. Alharbi (2017) investigated determinants of Islamic banks' profitability in international bank from 1992 to 2008. Using unbalanced panel data fixed-effects regression model. Total asset is positive significant related to Islamic banks' profitability.

Amzal (2016) analyse the impact of macroeconomic variables on Indonesia Islamic banks profitability period from 2006 to 2012 . The result showed that GDP is positive and significant on Islamic banks profitability by ROA. Ali et al, (2018) and Salike \& Ao (2018) found that GDP is positive related to profitability bank's in Asia. Abel \& Leroux (2016) investigated the determinants of banking sector profitability in Zimbabwe during the period 2009-2014. The result show that GDP have negative and significant impact on banking sector profitability in Zimbabwe. Nuriyeva (2013) examined factor affecting the profitability of banking system in Krygyzstan. The result showed that GDP have negative and significant impact on bank profitability.

The literature has profoundly discussed the significance of inflation especially its relationship with banks performance. Inflation not only impacts corporates' pricing but also has significant influence on bank customers and financial resources (Ali et al., 2018). Tan \& Floros (2012) examined the determinant of bank profitability in China period under consideration extends from 2003-2009. Using OLS and fixed effects models generalized methods of moments (GMM). The results show that inflation is positive related to bank profitability. Ali et al., (2018) examined impact of macroeconomic variables on Islamic bank profitability period from 2012-2016. The findings that inflation have a positive and significant impact on Islamic bank profitability.

\section{Research Methodology}

In this study, bank profitability is the dependent variable, while bank specific and macroeconomic variables are the independent variables. The main objective of the present paper is to investigate the long-run and short-run relationships between profitability of Islamic banks and its determinants over the period 2010 - 2018. In this study using montly time series data and collected from different sources. Bank specific variables are Return on Asset (ROA), Capital Adequacy Ratio (CAR), Non Performing Finance (NPF), Finance to Deposit Ratio (FDR), 
Operating Cost of Operating Income (BOPO), Total Aset (bank Size) from Otoritas Jasa Keuangan (https://ojk.go.id); Economic growth rate is proxied by Industrial Production Index variables were collected from the Central Bureau of Statistics Indonesia (http://www.bps.go.id); and Inflation variable is collected from the Bank Indonesia (http://www.bi.go.id).

Table 2.1 Definition and notation of the variable profitability of Islamic rural banks

\begin{tabular}{|c|c|c|}
\hline Variables & Description & Symbol \\
\hline \multicolumn{3}{|c|}{ Dependent variable } \\
\hline $\begin{array}{l}\text { Bank } \\
\text { profitability }\end{array}$ & Return on Asset & ROA \\
\hline \multicolumn{3}{|c|}{ Independent variables } \\
\hline Capital ratio & $\begin{array}{l}\text { Capital Adequacy } \\
\text { Ratio }\end{array}$ & CAR \\
\hline Liquidity ratio & $\begin{array}{ll}\text { Financing } & \text { to } \\
\text { Deposit Ratio }\end{array}$ & FDR \\
\hline $\begin{array}{l}\text { Financing risk } \\
\text { ratio }\end{array}$ & $\begin{array}{l}\text { Non-Performing } \\
\text { Financing }\end{array}$ & NPF \\
\hline $\begin{array}{l}\text { Operational cost } \\
\text { ratio }\end{array}$ & $\begin{array}{l}\text { Operating Cost of } \\
\text { Operating Income }\end{array}$ & $\mathrm{BOPO}$ \\
\hline Bank size & $\begin{array}{l}\text { Natural log of total } \\
\text { asset }\end{array}$ & LnTA \\
\hline $\begin{array}{l}\text { Industrial } \\
\text { Production } \\
\text { Index }\end{array}$ & $\begin{array}{l}\text { Monthly growth } \\
\text { rate }\end{array}$ & IPI \\
\hline Inflation & $\begin{array}{l}\text { Monthly inflation } \\
\text { rate }\end{array}$ & INFL \\
\hline
\end{tabular}

Source: Author estimate

To investigated the long-run and short-run relationships between bank profitability and their determinants, several steps of the methodology were used. In economic and financial analyses, stationarity tests are conducted to determine the stationarity of time series data. This study started by exploring the stationarity properties of the series using the Augmented-Dickey-Fuller (ADF) and Philip-Perron (PP) tests procedure. This test is done in the first place in order to avoid spurious regression which is a cammon problem among most of the macroeconomic variables whose data generation processes follow a time trend. If the variables are stationarity at second difference, the computed F-statistics are not valid because based on the assumption that the variables must be stationarity at level, first difference or both.

However in an economic view, the variables will be co-integrated if they have a long-run or equilibrium relationship between each other (Bekhet \& Al-Smadi, 2015). The cointegration test was applied to determine which model will be suitable for the current study. The estimates long-run and short-run relationships simultaneously, and allows the test on existence of relationships between variables for stasionary data at various levels, and first difference or both. Equation (1) long-run relationship between bank profitability and its determinant, we arrive at:

$$
\begin{aligned}
R O A_{t}=\beta_{0}+ & \beta_{1} C A R+\beta_{2} N P F_{t}+\beta_{3} F D R_{t} \\
& +\beta_{4} B O P O_{t}+\beta_{5} L n T A_{t}+\beta_{6} I P I_{t} \\
& +\beta_{7} I N F L_{t}+\varepsilon_{t}
\end{aligned}
$$

Differencing Equation (1) as a result of nonstationarity nature of the variables, give Equation (2), the bank profitability equation is then stated as:

$$
\begin{aligned}
\triangle R O A_{t}=\beta_{0}+ & \beta_{1} \Delta C A R+\beta_{2} \Delta N P F_{t} \\
& +\beta_{3} \Delta F D R_{t}+\beta_{4} \Delta B O P O_{t} \\
& +\beta_{5} \Delta L n T A_{t}+\beta_{6} \Delta I P I_{t} \\
& +\beta_{7} \Delta I N F L_{t}+\varepsilon_{t}
\end{aligned}
$$

Where $\beta_{0}, \beta_{1}, \beta_{2}, \beta_{3}, \beta_{4}, \beta_{5}, \beta_{6}$ and $\beta_{7}$, are the parameters to be determined, $\mathrm{t}$ and $\varepsilon$ denote time and error, respectively.

\section{Result and Discussion}

\subsection{Research result}

Table 3.1 show that correlation matrix result of the variables used in the paper. The correlation matrix for the key variables is presented. ROA has a positive and strong correlation with CAR, FDR, NPF, BOPO, LnTA, IPI, while INFL have negative and low correlation with ROA. These results support the existing literature that CAR, FDR, NPF, LnTA, and IPI are important diterminants for ROA. 
Jurnal Ilmiah Ekonomi Islam, 5(03), 2019, 321

Table 3.1 Correlation matrix result

\begin{tabular}{ccccccccc}
\hline Variables & ROA & CAR & FDR & NPF & BOPO & LNTA & IPI & INFL \\
\hline ROA & 1 & & & & & & & \\
CAR & 0.681 & 1 & & & & & & \\
FDR & 0.695 & 0.823 & 1 & & & & & \\
NPF & 0.605 & 0.798 & 0.793 & 1 & & & & \\
BOPO & 0.417 & 0.804 & 0.816 & 0.859 & 1 & & & \\
LNTA & 0.670 & 0.698 & 0.309 & 0.840 & 0.634 & 1 & & \\
IPI & 0.609 & 0.658 & 0.681 & 0.872 & 0.643 & 0.962 & 1 & \\
INFL & -0.023 & -0.040 & 0.048 & -0.3546 & -0.145 & -0.317 & -0.374 & 1 \\
\hline
\end{tabular}

The stationary test is an important step in analysing time series data. Table 3.2 showed that result of ADF and PP unit root test indicate that all the variables are stationary at first difference in intercept at the same significance levels. Unit root test used at $1 \%, 5 \%$, and $10 \%$ significance levels.

Table 3.2 Stationary test result

\begin{tabular}{|c|c|c|c|c|}
\hline Test equation includes & Variables & ADF & PP & Results \\
\hline & Level & & & \\
\hline \multirow[t]{9}{*}{ Intercept } & $\mathrm{ROA}$ & $-3.697 * *$ & $-3.472 * * *$ & Stationary \\
\hline & CAR & $-2.694 *$ & $-2.566^{*}$ & Stationary \\
\hline & FDR & -1.790 & -1.837 & Nonstationary \\
\hline & NPF & -1.056 & -0.966 & Nonstationary \\
\hline & BOPO & -1.462 & -1.751 & Stationary \\
\hline & LNTA & $-3.191 * *$ & $-3.656 * * *$ & Stationary \\
\hline & IPI & -0.358 & -0.890 & Nonstationary \\
\hline & INFL & $-2.502 *$ & -2.088 & Nonstationary \\
\hline & First difference & & & \\
\hline \multirow[t]{8}{*}{ Intercept } & ROA & $-13.748 * * *$ & $-15.883 * * *$ & Stationary \\
\hline & CAR & $-9.550 * * *$ & $-11.507 * * *$ & Stationary \\
\hline & FDR & $-9.816 * * *$ & $-9.814 * * *$ & Stationary \\
\hline & NPF & $-11.413 * * *$ & $-11.430 * * *$ & Stationary \\
\hline & BOPO & $-14.719 * * *$ & $-15.059 * * *$ & Stationary \\
\hline & LNTA & $-10.826 * * *$ & $-10.944 * * *$ & Stationary \\
\hline & IPI & $-12.696 * * *$ & $-49.795 * * *$ & Stationary \\
\hline & INFL & $-7.743 * * *$ & $-7.512 * * *$ & Stationary \\
\hline
\end{tabular}

Notes: ADF is the augmented Dickey-Fuller unit root test. PP is the Phillips-Perron unit root test. *, **, $* * *$ indicated significance at $10 \%, 5 \%$, and $1 \%$ levels, respectively.

The result of the cointegration test with Johansen. Tabel 3.4 showed that ROA variable cointegration with all variables such as CAR, FDR, NPF, BOPO, LnTA, IPI and INFL at 5\% significance levels. This test confirmed that relationships between ROA and its deteminants are cointegrated.

Table 3.3 The result of Johansen for cointegration test

\begin{tabular}{|c|c|c|c|c|c|}
\hline $\begin{array}{c}\text { Hypothesized } \\
\text { No. of CE(s) }\end{array}$ & Eigenvalue & $\begin{array}{c}\text { Trace } \\
\text { Statistic }\end{array}$ & $\begin{array}{c}\mathbf{0 . 0 5} \\
\text { Critical Value }\end{array}$ & Prob.** & Result \\
\hline None $^{*}$ & 0.377137 & 191.8075 & 159.5297 & 0.0003 & Cointegrated \\
\hline
\end{tabular}


Jurnal Ilmiah Ekonomi Islam, 5(03), 2019, 322

\begin{tabular}{|c|c|c|c|c|c|}
\hline At most 1 * & 0.317328 & 142.0975 & 125.6154 & 0.0033 & Cointegrated \\
\hline At most 2 * & 0.282821 & 102.0148 & 95.75366 & 0.0173 & Cointegrated \\
\hline At most 3 & 0.230423 & 67.10974 & 69.81889 & 0.0807 & Noncointegrated \\
\hline At most 4 & 0.178975 & 39.60871 & 47.85613 & 0.2368 & Noncointegrated \\
\hline At most 5 & 0.099338 & 18.90251 & 29.79707 & 0.5000 & Noncointegrated \\
\hline At most 6 & 0.056484 & 7.916857 & 15.49471 & 0.4743 & Noncointegrated \\
\hline At most 7 & 0.017109 & 1.811942 & 3.841466 & 0.1783 & Noncointegrated \\
\hline
\end{tabular}

Notes: Trace test indicates 2 cointegrating at the $5 \%$ level.

Table 3.4 The result of Error Correction Model (ECM)

\begin{tabular}{ccc}
\hline & Long-run & \\
\hline Variables & Coeffecient & t-stattistic \\
ROA(-1) & 1.000000 & \\
CAR(-1) & $\mathbf{0 . 1 8 9 9 9 7}$ & $\mathbf{2 . 5 3 9 0 3}$ \\
NPF(-1) & $\mathbf{- 0 . 8 3 0 6 4 2}$ & $\mathbf{- 5 . 7 1 7 6 2}$ \\
FDR(-1) & 0.027826 & 1.35196 \\
BOPO(-1) & $\mathbf{- ~ 0 . 2 0 4 0 0 4}$ & $\mathbf{- 3 . 2 1 6 0 3}$ \\
LNTA(-1) & $\mathbf{8 . 5 9 3 0 8 6}$ & $\mathbf{7 . 3 6 2 5 8}$ \\
IPI(-1) & $\mathbf{- 0 . 3 9 9 1 2 5}$ & $\mathbf{- 8 . 2 5 8 1 5}$ \\
INFL(-1) & 0.004966 & 0.05181 \\
\hline & Short-run & \\
\hline CointEq1 & 0.002896 & 0.14291 \\
D(ROA(-1)) & -0.224573 & -1.54138 \\
D(CAR(-1)) & -0.004981 & -0.29376 \\
D(NPF(-1)) & -0.008277 & -0.19616 \\
D(FDR(-1)) & 0.006645 & 0.91177 \\
D(BOPO(-1)) & 0.011349 & 0.94240 \\
D(LNTA(-1)) & 2.808479 & 1.53342 \\
D(IPI(-1) & -0.002255 & -0.37962 \\
D(INFL(-1) & 0.012799 & 0.41707 \\
\hline
\end{tabular}

Tables 3.5 present the result error correction model in long-run and short-run. There are several bank specific and macroeconomic variables that have a significant effect on the profitability of Islamic banks. In long run we found that five variables are statistically significant such as CAR, NPF, BOPO, LnTA, and IPI. While two variables insignificant such as FDR and INFL. In short run all independent variables insignificant with ROA.

\subsection{Discussion}

The coefficient of capital adequacy ratio (CAR) is positive and significant to profitability of Islamic bank. The results of this study are similar to the findings with research AL-Omar \& AL-Mutairi (2008) and Salike \& Ao (2018) found that capital adequacy is positive and significant related to bank profitability. Capital adequacy ratio (CAR) is the bank's capital adequacy ratio or the ability of banks in existing capital to cover possible losses in financing. A good capital adequacy ratio can improve the performance of the bank's operations, in financing there are sometimes losses in financing so that it can hinder the refund of funds from customers. banks with good capital adequacy ratios can conduct financing restructuring to reduce problems in the customer's business. With the condition that the restructured business has potential in the future. The normal state of the customer's business can delay the return of financing, so that it can affect the level of profitability of the bank.

The coefficient of Financing to Deposit Ratio (FDR) insignificant on profitability of Islamic banks. This result is similar with finding Yudha et al., (2017) that loan to deposit ratio in domestic bank insignificant influence to bank profitability. While contrary with Erlangga \& Mawardi (2016) finding that Financing to Deposit Ratio (FDR) has a positive and significant on profitability of Islamic bank. FDR does not significantly affect the profitability of Islamic rural banks which shows that the performance of Islamic banks is not efficient in maximizing funds lent to customers, so Islamic banks face an increasing number of NonPerforming Finance (NPF), this will certainly add costs to Islamic banks . FDR can not directly affect the profitability of Islamic banks, meaning 
that a high FDR without followed by good financing procedures will increase the NPF. If the Islamic bank's NPF is high it can reduce bank profitability, according to the results of research that show that NPF and profitability have a negative relationship. This indicates that a high NPF can reduce profitability, conversely a low NPF can increase the profitability of Islamic rural banks.

The coefficient of non performing finance (NPF) is negative and significant to profitability of Islamic bank. The results of this study are similar to the findings with research Laryea et al., (2016) and Yudha et al., (2017) that non performing finance is negative and significant impact to profitability of Islamic bank. This study shows that the greater the Non-Performing Finance will result in the decrease in bank profitability, the bank's financial performance decreases due to increasingly problematic financing. Conversely, if the Non-Performing Finance ratio decreases, the bank's profitability will increase, which means the bank's financial performance will improve. Good financing depends on the businesses that will be given financing, the business potential of the customer becomes a determining factor for the profits obtained by the bank. In addition, bank supervision is the key to reducing the problematic financing faced by customers.

Non-Performing Finance (NPF) reflects the risk of financing, a high NPF ratio will indicate increasingly poor financing quality at Islamic banks. Good financing management is very important for Islamic banks, because the financing function is the biggest revenue contributor for Islamic banks. The level of health of financing will affect the achievement of profitability of Islamic banks. The increase in NPF will result in loss of opportunity to obtain income from financing provided so that it can affect the level of profitability of Islamic rural banks.

Problem financing is a negative impact of the emergence of financing on customers. Financing problems is not only due to macroeconomic factors, but is related to financing problems related to moral hazard. To minimize problematic financing, employees at Islamic rural banks must be honest and selective in choosing customers who will conduct financing.

The coefficient of Operating Cost of Operating Income (BOPO) is negative and significant to profitability of Islamic bank. Banks that have efficient operational costs can improve the performance of bank profitability. The results of this study are similar to the findings by Kusumastuti \& Alam (2019) and Wibowo \& Syaichu (2013) found that operating cost of operating income has a negative significant effect on profitability of Islamic bank. Operating Cost of Operating Income (BOPO) is a measure of efficiency related to cost control. The coefficient negative of BOPO indicates there is an inverse relationship between BOPO and profitability. The smaller BOPO ratio shows that operational costs incurred by Islamic banks are more efficient. This indicates that the management of Islamic banks is very efficient in carrying out operational activities. Operating expenses in Islamic banks are affected by the growth of overhead costs. An efficient Islamic bank in carrying out its operational activities can increase profitability. Conversely, Islamic banks that are not efficient in carrying out operational activities will reduce the profitability of Islamic rural banks.

Total asset (LnTA) is positive and significant to profitability of Islamic bank. The results of this study are similar to the findings by Masood \& Ashraf (2012), AL-Omar \& ALMutairi, (2008) and Alharbi (2017) that total asset is positive significant related to profitability of Islamic banks. Bank size is measured by total assets, the large number of assets makes the company provide financing to customers in larger amounts. Total assets are a determining factor in generating profits for banks as long as the use of funding is given to potential businesses. Banks with large total assets can work efficiently compared to smaller banks. the 
greater the total assets of a bank, the greater the chance to make a profit.

The Industrial Production Index (IPI) is negative and significant to profitability of Islamic bank. This study similar to the findings with research Abel \& Leroux (2016) and Nuriyeva, (2013) that GDP have negative and significant impact on bank profitability. This study contrary with Amzal (2016) and Ali et al., (2018) that GDP is positive related to profitability bank's in Asia.

The result show that inflation insignificant impact on profitability of Islamic banks. This study similar to the findings with research Wibowo \& Syaichu, (2013) and Garcia \& Trindade (2019). Basically, inflation reflects an increase in the price of goods continuously which is influenced by an increase in the money supply. Inflation does not have a direct effect on bank profitability. A high inflation rate can reduce the amount of deposits and savings in banks which can affect savings funds which are used as a source of income for banks. However, in this study, the impact of inflation was not significant on profitability in Islamic banks.

\section{Conclutions}

This study attemepts to asses the impact of bank specific and macroeconomic variables on profitability of Islamic rural bank in Indonesia. Using monthly data time series period from Januari 2010 - Desember 2018. The estimate model using vector error correction model to analyse relationships long-run and short-run between bank specific and macroeconomics variables with profitability of Islamic rural bank. The results indicate that CAR and LnTA have positive significant related, while NPF, BOPO and IPI are negative significant related on profitability of Islamic rural bank. Variables FDR and Inflation are insignificant related to profitability of Islamic rural bank.

The result leave implications to palicymakers, investors and banking sector managers. Viewing evidence about drives bank's profitability of Islamic rural bank will help them understand which factors are critical to track and analyse in order to attain higher profitability.

\section{Acknowledgements}

The authors would like to thank all the lecturers Master of Islamic Economics at Airlangga University who have helped provide input on this paper. And then the authors would like to thank the editors and reviewers for helpful comments.

\section{Daftar Pustaka}

Abel, S., \& Leroux, P. (2016). Determinants of Banking Sector Profitability in Zimbabwe. International Journal of Economics and Financial Issues, 6(3), 845-854.

AL-Omar, H., \& AL-Mutairi, A. (2008). BankSpecific Determinants of Profitability: The case of Kuwait. Journal of Economic and Administrative Sciences, 24(2), 20-34. Retrieved from https://doi.org/10.1108/10264116200300006 99

Alharbi, A. T. (2017). Determinants of Islamic banks' profitability: international evidence. International Journal of Islamic and Middle Eastern Finance and Management, 10(3), 331-350. https://doi.org/10.1108/IMEFM12-2015-0161

Ali, Q., Maamor, S., Yaacob, H., \& Gill, M. U. T. (2018). Impact of Macroeconomic Variables on Islamic Banks Profitability. Journal of Accounting and Applied Business Research, 1(2), 1-16.

Amzal, C. (2016). The Impact of Macroeconomic variables on Indonesia Islamic Banks Profitability. Jurnal Ekonomi Dan Bisnis Islam, 2(1), 71-86.

Bekhet, H. A., \& Al-Smadi, R. W. (2015). Determinants of Jordanian foreign direct investment inflows: Bounds testing approach. Economic Modelling, 46, 27-35. https://doi.org/10.1016/j.econmod.2014.12.0 27

Erlangga, O. P., \& Mawardi, I. (2016). Pengaruh Total Aktiva, Capital Adequacy Ratio (CAR), Finance To Deposit Ratio (FDR) 
dan Non Performing Financing (NPF) Terhadap Return on Assets (ROA) Bank Umum Syariah Di Indonesia Periode 20102014. Jurnal Ekonomi Syariah Teori Dan Terapan, 3(7), 561-574. https://doi.org/dx.doi.org/10.20473/vol3iss2 0167pp561

Garcia, M. T. M., \& Trindade, M. J. (2019). Determinants of banks' profitability in Angola. African Journal of Economic and Management Studies, 10(1), 116-128. https://doi.org/10.1108/AJEMS-06-20180161

Kusumastuti, W. I., \& Alam, A. (2019). Analysis of Impact of CAR, BOPO, NPF on Profitability of Islamic Banks (2015-2017). Journal of Islamic Economic Laws, 2(1), 30-59.

Laryea, E., Ntow-Gyamfi, M., \& Alu, A. A. (2016). Nonperforming loans and bank profitability: evidence from an emerging market. African Journal of Economic and Management Studies, 7(4), 462-481. https://doi.org/10.1108/AJEMS-07-20150088

Masood, O., \& Ashraf, M. (2012). Bank-specific and macroeconomic profitability determinants of Islamic banks: The case of different countries. Qualitative Research in Financial Markets, 4(2-3), 255-268. https://doi.org/10.1108/17554171211252565

Masood, O., Ashraf, M., \& Turen, S. (2015). Bank-Specific and Macroeconomic Determinants of Bank Profitability: Evidence from Member States of the OIC. Journal of Islamic Financial Studies, 1(1), 43-51. https://doi.org/10.12785/jifs/010104

Menicucci, E., \& Paolucci, G. (2016). The determinants of bank profitability: empirical evidence from European banking sector. Journal of Financial Reporting and Accounting, 14(1), 86-115. https://doi.org/10.1108/JFRA-05-2015-0060 Nuriyeva, Z. (2013). Factors Affecting the Profitability of Banking System in Kyrgyzstan. Thesis Master of Science in Banking and Finance, (January), 1-55.

Salike, N., \& Ao, B. (2018). Determinants of bank's profitability: role of poor asset quality in Asia. China Finance Review International, $\quad 8(2), \quad$ 216-231. https://doi.org/10.1108/CFRI-10-2016-0118

Shaban, M., Duygun, M., Anwar, M., \& Akbar, B. (2014). Diversification and banks' willingness to lend to small businesses: Evidence from Islamic and conventional banks in Indonesia. Journal of Economic Behavior and Organization, 103, S39-S55. https://doi.org/10.1016/j.jebo.2014.03.021

Tan, Y., \& Floros, C. (2012). Bank profitability and inflation: The case of China. Journal of Economic Studies, 39(6), 675-696. https://doi.org/10.1108/01443581211274610

Wibowo, E. S., \& Syaichu, M. (2013). Analisis Pengaruh Suku Bunga, Inflasi, CAR, BOPO, NPF Terhadap Profitabilitas Bank Syariah. Diponegoro Journal of Management, 2(2), 1-10.

https://doi.org/http://hdl.handle.net/10986/22 167

Yudha, A., Chabachib, M., \& Pangestuti, I. R. D. (2017). Analysis of The Effect of NPL, NIM, Non Interest Income, and LDR Toward ROA with Size as Control Variables (Differences Study on Domestic and Foreign Banks Listed on BEI Period 2010-2015). Jurnal Bisnis Strategi, 26(2), 100-113. 